\title{
Response of Mung Bean Varieties (Vigna radiata L.) to Application Rates and Methods of Blended NPS Fertilizer at Humbo
}

\author{
Fekadu Mekonen Mota, ${ }^{1}$ Dereje Shanka Balla, ${ }^{1}$ and Mesfin Bibiso Doda ${ }^{2}{ }^{2}$ \\ ${ }^{1}$ Department of Plant Science, College of Agriculture, Wolaita Sodo University, Wolaita Sodo, Ethiopia \\ ${ }^{2}$ Department of Chemistry, College of Natural and Computational Science, Wolaita Sodo University, Wolaita Sodo, Ethiopia
}

Correspondence should be addressed to Mesfin Bibiso Doda; mefbab2009@gmail.com

Received 22 May 2021; Revised 22 October 2021; Accepted 23 October 2021; Published 18 November 2021

Academic Editor: David Clay

Copyright (C) 2021 Fekadu Mekonen Mota et al. This is an open access article distributed under the Creative Commons Attribution License, which permits unrestricted use, distribution, and reproduction in any medium, provided the original work is properly cited.

\begin{abstract}
Mung bean is among the important dry-land legumes in the country and in the study area. However, the productivity of the crop is constrained by biotic and abiotic factors, mainly poor soil fertility, lack of adaptable varieties, and peer agronomic practices. Field trial was initiated at Humbo District with the objective of investigating the rate of NPS-blended fertilizer and application methods on overall performance of mung bean (Vigna radiata L.) varieties. The treatments comprised factorial combination of four rates of NPS $\left(0,50,100\right.$, and $\left.150 \mathrm{~kg} \mathrm{ha}^{-1}\right)$, two types of application methods (broadcasting and drilling), and two mung bean varieties (Shewa Robit and N-26) laid out in RCBD with three replications. Analysis of variance revealed that NPS rates and varieties significantly affected phenology and yield components. Application methods affected yield and thousand-seed weight. Two-way interaction of NPS rates with varieties significantly influenced plant height and pod plant ${ }^{-1}$. Three-way interactions also significantly influenced aboveground dry biomass and grain yield. The greatest dry biomass $\left(4273.7 \mathrm{~kg} \mathrm{ha}^{-1}\right)$ and grain yield $\left(1539.2 \mathrm{~kg} \mathrm{ha}^{-1}\right.$ ) were produced by N-26 variety with fertilizer composed of NPS at $150 \mathrm{~kg} \mathrm{ha}^{-1}$ using the drill application method. Partial budget analysis also revealed that the highest (ETB 46,934.4 ha ${ }^{-1}$ ) net benefit was obtained at $100 \mathrm{~kg} \mathrm{NPS} \mathrm{ha}^{-1}$ with variety N-26 from the drilled method. Hence, growing N-26 with $100 \mathrm{~kg}$ NPS ha ${ }^{-1}$ applied using the drilling method of fertilizer application was found as the most suitable treatment combination to improve the income of farmers and increase productivity of mung bean.
\end{abstract}

\section{Introduction}

Mung bean (Vigna radiata L.) is amongst the important pulses cultivated in different agro ecological zones of the world [1]. It is known for its high vitamin A and protein, which can supply a balanced diet when taken in mixture with cereal, which contains low level of protein [2]. It is a short maturity and drought resistance crop, which conferees its adaptation to adverse environmental conditions and successfully grows in rain-fed areas [3]. Furthermore, it is adaptable for the semiarid and arid areas due to its short growing cycle [4], which may be related to attainment of the required degree days to reach maturity in a short period of time due to high temperature condition.
Mung bean is locally called "Masho" in Amharic. It is a pulse crop that is recently introduced and cultivated in a limited area in low scale [5]. Mung bean is an important pulse crop for smallholders that have recently gained attention and announced as the sixth export commodity by Ethiopian Commodity Exchange [6]. In Ethiopia, mung bean is produced at about $41,633.2$ ha with total production of 514,227.41 $\mathrm{t}$ and the average productivity of $1.23 \mathrm{tha}^{-1}$ [7]. Similarly, the current regional production is estimated at 122.14 ha with total production of $1150.63 \mathrm{t}$ and the average productivity of mung bean is $0.94 \mathrm{t} \mathrm{ha}^{-1}$ [7]. There was huge gap between its potential and regional average productivity of $0.94 \mathrm{t} \mathrm{ha}^{-1}$ and national average productivity of $1.23 \mathrm{t}$ $\mathrm{ha}^{-1}$, yet the yield gap is not narrowed. To this end, in 
Ethiopia, the confirmed yield potential reaches 1.5 tons under research field and 0.5 to $1.0 \mathrm{t} \mathrm{ha}^{-1}$ under farmer field with research recommended practices [8]. The low yields are ascribed to the lack of improved seeds, susceptible to disease, inadequate agricultural practices, and less awareness to farmers regarding production of the crop [9].

Different authors reported low productivity of mung bean in Ethiopia compared to the production reported in other countries around the globe, which might be attributed to low soil fertility, which is also attributed to the limited use of inorganic fertilizer [9]. Both macronutrients and micronutrients increase nitrogen $(\mathrm{N})$ fixation and the growth of mung bean plant. Like other legumes, it requires nutrients like $\mathrm{N}$, phosphorus $(\mathrm{P})$, and sulfur $(\mathrm{S})$ for growth and development [10].

Nitrogen containing fertilizers are essential for crops as source of proteins and play beneficial roles on crop performance, which contribute for maximizing production [11].

Application of phosphorus with other micronutrients can increase the production [12]. Generally, P fertilizer is applied as a starter fertilizer before planting. Application of $\mathrm{P}$ can enhance root growth, improving flower formation and seed production [13]. The most commonly used fertilizers in Ethiopia were $\mathrm{N}$ and $\mathrm{P}$, but they are not the only yield constraining elements. For instance, sulfur $(S)$ is recently identified to be low in most soils [14]. Therefore, $S$ is among the sixteen essential elements, which are important for many reactions and functions in all living cells and the fourth major nutrient, following NPK [15].

In production of mung bean, inadequate use of fertilizer, absence of improved varieties, and application methods are among the important problems. The production of mung bean can be highly affected by nutrient management [16]. However, in Ethiopia, little has been done on the growth parameters of mung bean and on its production constraints in the past [17]. Responses to different varieties of mung bean to rates and application methods of fertilizer composed of NPS have not been examined adequately. Therefore, the purpose of this work is to generate information on influences of different rates and application methods of fertilizer composed of NPS for production of mung bean. Thus, this study was focused on the effects of fertilizer composed of NPS at different rates and application methods on production of mung bean varieties and identify economically optimum NPS fertilizer rate for mung bean production.

\section{Materials and Methods}

2.1. Description of the Study Area. The trial was executed at Abala Faracho kebele, Humbo district in Wolaita Zone, Southern Ethiopia. The site was located at $6^{\circ} 39^{\prime} 59.99^{\prime \prime} \mathrm{N}$ latitude and $37^{\circ} 49^{\prime} 59.99^{\prime \prime} \mathrm{E}$ longitude at an altitude range of 1001 to 2000 masl. The area receives annual rainfall of $50-300 \mathrm{~mm}$. The monthly mean maximum temperature $(T)$ of the area is $32^{\circ} \mathrm{C}$, while its minimum temperature is $15.5^{\circ} \mathrm{C}$ [18]. The soil type of experimental site is silty clay.
2.2. Experimental Materials. Blended NPS fertilizer used for this experiment was obtained from Wolaita Sodo University. Nutrients composition of $100 \mathrm{~kg}$ of NPS is $19 \mathrm{~kg} \mathrm{~N}, 38 \mathrm{~kg}$ $\mathrm{P}_{2} \mathrm{O}_{5}, 0 \mathrm{~kg} \mathrm{~K} \mathrm{O}_{2}, 7 \mathrm{~kg} \mathrm{~S}, 0 \mathrm{~kg} \mathrm{Zn,0} \mathrm{kg} \mathrm{B} \mathrm{(EthioSIS,} \mathrm{2016).}$ Mung bean varieties, N-26 and Shewa Robit, were used, which were obtained from Melkassa Agricultural Research Center, and released in 2011. Their yield potential is 1.5 and $1.00 \mathrm{t} \mathrm{ha}^{-1}$ at research and farmer's field, respectively. By now, they are widely adapted at different areas and produced by most producers for domestic consumption as well as for export.

2.3. Treatments and Experimental Design. Factorial combinations of mung bean varieties (Shewa Robit and N-26), four different levels of fertilizer composed of NPS $(0,50,100$, and $150 \mathrm{~kg}$ NPS ha ${ }^{-1}$ ), and two types of application method of fertilization Broadcast and drill (subsurface application at $5 \mathrm{~cm}$ soil depth) were used. Totally, 16 treatments were assigned randomly on experimental plots on N-26 and Shewa Robit mung bean varieties. Factorial randomized complete block design (RCBD) was used for laying out experiment with 3 replicates. Plot size was $2.1 \mathrm{~m} \times 3 \mathrm{~m}$ with $6.3 \mathrm{~m}^{2}$ area having 7 rows. Plots and blocks were separated 1 and $1.5 \mathrm{~m}$ apart, respectively, and total experimental area was $15 \mathrm{~m} \times 50.6 \mathrm{~m}\left(759 \mathrm{~m}^{2}\right)$.

\subsection{Experimental Procedures and Agronomic Managements.} The field was ploughed three times by oxen, leveled, and prepared. Variety N-26 and Shewa Robit were sown on 10 May 2019, which was medium rainfall season. Two seeds per hole were planted in the row. Different rates of blended N, P, and $S$ fertilizers were applied either by drill or broadcast method at sowing time for the respective treatment combination. In drill application method, NPS fertilizer was applied at $5 \mathrm{~cm}$ depth and covered with soil before sowing. Then, sowing was performed at 30 and $10 \mathrm{~cm}$ inter- and intrarow spacing respectively. Agronomic practices such as weeding, plant spacing, and disease management were kept uniform for all the experimental units.

2.5. Soil Sample Collection and Analysis. The studied soil samples were collected at $0-30 \mathrm{~cm}$ depth by zigzag method from different spots in the experimental field before planting by using soil auger. Then, the collected soil sample was airdried, grounded to pass through a $2 \mathrm{~mm}$ sieve, thoroughly mixed, and made ready for physicochemical analysis.

Laboratory analyses were done at Horticoop Ethiopia Laboratory at Debre-Zeit. Before planting, the collected soil sample was used for analyzing selected soil physicochemical properties [19]. Total \% of N was analyzed by the Kjeldah method [20], and available P, S, B, and Zn were analyzed by the Mehlich III method [21], percent of organic carbon content was analyzed using method as described by Reeuwijk [22], and soil $\mathrm{pH}$ was determined using a $\mathrm{pH}$ meter (Belgium, C835), following standard laboratory procedure [23]. 
2.6. Crop Data Collection and Analysis. All phenological and yield component data were collected following standard procedure. Accordingly data were collected on days to $50 \%$ flowering and days to $90 \%$ flowering, height of the plant $(\mathrm{cm})$, number of primary branches, and leaf area index (LAI), calculated as the ratio of total leaf area per five plants $\left(\mathrm{cm}^{2}\right)$ per area of land occupied by the plants using standard procedure, number of pods per plant, number of seeds per pod, thousand-seed weight (g), grain yield, aboveground biomass $(\mathrm{kg} / \mathrm{ha})$, and harvest index. Leaf area was measured using leaf area meter from five plants in rows left for destructive sampling at maximum vegetative growth stage. Aboveground dry biomass yield was measured from five randomly selected plants from rows left for destructive sampling at physiological maturity and converted to hectare base. Grain yield was measured from the net plot area at harvest and adjusted to $10 \%$ moisture content. Harvest index (HI) was calculated as the ratio of grain yield to total aboveground dry biomass yield multiplied by 100 .

2.7. Economic Analysis. Economic analysis was done using partial budget analysis according to the methods described by [24]. All varying costs were recorded and used for this analysis. Gross field benefits (GFB) $\mathrm{ha}^{-1}$ were determined by multiplying adjusted grain yield $\left(\mathrm{kg} \mathrm{ha}^{-1}\right)$ by market price at the time of harvest. Adjusted grain yield was calculated by reducing average grain yield by $10 \%$ to avoid overestimation of mung bean yield. Marginal rate of return (\%) was calculated by taking the change in benefit to change in cost multiplied by 100 . Total revenue (TR) is estimated as $\mathrm{TR}=$ adjusted yield $(\mathrm{AY}) \times$ field price of the grain, and the gross field benefit for each treatment is calculated by multiplying the field price by the adjusted yield. Net revenue (NR) is computed as $\mathrm{NR}=\mathrm{TR}$ - total variable cost (TVC). Value cost ratio (VCR) was estimated by dividing yield increase by cost of fertilizer used.

2.8. Data Analysis. The data collected was analyzed using SAS version 9.0 [25] and following the steps described by Gomez and Gomez [26]. Interpretations were made. Mean comparison was done for significant treatments using the LSD test at $5 \%$ probability level.

\section{Results and Discussion}

3.1. Physicochemical Properties of Soil. The studied soil is characterized by silty clay texture. The studied soil $\mathrm{pH}$ was analyzed to be 6.83 , which is moderately acidic. The analysis for other soil chemical properties is shown in Table 1.

According to [27], the best production of mung bean requires sandy loam soil with good drainage at $\mathrm{pH}$ of 6.3-7.2. Neutral soil with $\mathrm{pH}$ of 6.7-7.3 and silty clay soil texture class might have less drainage problem for mung bean. According to the study of [28], the soil in the study site was deficient of N, P, and S. From composite soil sample of the studied site, total concentration organic carbon, N, P, and $\mathrm{S}$, and their ratings were shown in Table 1.
TABLE 1: Selected soil properties before planting.

\begin{tabular}{lccc}
\hline Soil characters & Values & Rating & Reference \\
\hline Soil texture & & & \\
$\quad$ Sand (\%) & 20 & & \\
$\quad$ Clay (\%) & 40 & & \\
Silt (\%) & 40 & & \\
\hline Textural class & Silty clay & & \\
pH (water) & 6.83 & Moderate acidic & {$[29]$} \\
Total N (\%) & 0.13 & Moderate & {$[29]$} \\
Organic C (\%) & 1.39 & Moderate & {$[30]$} \\
Available P (mg/kg) & 27.25 & Moderate & {$[31]$} \\
Available S (mg/kg) & 47.87 & Moderate & {$[32]$} \\
\hline
\end{tabular}

\subsection{Phenological Parameters}

3.2.1. Days to Flowering. Results revealed that days to flowering were significantly influenced due to two-way interaction between NPS rates and varieties. Increased blended NPS rate significantly decreased the amount of days to flowering of mung bean varieties. Accordingly, the maximum days to flowering (40) were recorded from interaction of $150 \mathrm{~kg} \mathrm{ha}^{-1}$ blended NPS rate with variety Shewa Robit, whereas lowest days to flowering (33) were obtained from N-26 with no fertilizer applied (Table 2). The increased fertilizer rate has delayed flowering and maturity. Besides, application of S with NP fertilizer can enhance metabolic activity and nutrient utilization, which favors vegetative growth as reported by [33]. The study in [34] also reported increased vegetative growth with application of S $(20 \mathrm{~kg} \mathrm{~S}$ $\mathrm{ha}^{-1}$ ). On the contrary, the study in [35] reported that nonsignificant interaction was found for application of $\mathrm{P}$ with common bean variety on days to flowering.

3.2.2. Physiological Maturity. Delay in physiological maturity was observed with increase in blended NPS rate. The longer maturity date (71.66) was evidenced from interaction of $150 \mathrm{~kg} \mathrm{ha}^{-1}$ blended NPS rate with Shewa Robit, whereas the lowest maturity date (61.16) was attained from N-26 with no fertilizer applied (Table 2). Accordingly, maturity date prolonged following the increase in the level of NPS, which might be related to role of N in the NPS that enhanced vegetative growth. According to [33], it is observed that $\mathrm{N}$ improved luxuriant vegetative growth, thereby delaying maturity in mung bean. In contrast, the study in [36] reported no significant effect of application of $S\left(0-60 \mathrm{~kg} \mathrm{ha}^{-1}\right)$ on days to maturity on common bean.

\subsection{Growth Parameters}

3.3.1. Plant Height. Plant height increased with increased fertilizer rate for both varieties. The highest $(67.75 \mathrm{~cm})$ height of the plant was found for variety Shewa Robit at rate of $150 \mathrm{~kg}$ NPS ha ${ }^{-1}$, whereas the minimum height $(59.0 \mathrm{~cm})$ was obtained from Shewa Robit with no fertilizer applied (Table 2). Thus, the highest in plant height is probably due to genetically different character of varieties and increased NPS fertilizer by enhancing of root development and crop growth. It could also due to favorable climatic conditions until physiological 
TABLE 2: Interaction effects of NPS fertilizer rates with varieties on days to 50\% flowering (DF), days to $90 \%$ physiological maturity (DM), plant height $(\mathrm{PH})$, number of branches (NB), leaf area (LA), and leaf area indices (LAI).

\begin{tabular}{|c|c|c|c|c|c|c|c|}
\hline Varieties & NPS rates $\left(\mathrm{kg} \mathrm{ha}^{-1}\right)$ & DF & $\mathrm{DM}$ & $\mathrm{pH}(\mathrm{cm})$ & NB & LA $\left(\mathrm{cm}^{2}\right.$ plant $\left.^{-1}\right)$ & LAI \\
\hline \multirow{4}{*}{$\mathrm{N}-26$} & 0 & $33.00^{\mathrm{h}}$ & $61.16^{\mathrm{g}}$ & $61.76^{\mathrm{d}}$ & $6.2^{c}$ & $256.28^{\mathrm{e}}$ & $0.85^{\mathrm{e}}$ \\
\hline & 50 & $33.01^{\mathrm{g}}$ & $62.00^{f}$ & $62.66^{\mathrm{cd}}$ & $6.3^{b c}$ & $298.92^{\mathrm{cd}}$ & $0.99^{\mathrm{cd}}$ \\
\hline & 100 & $35.00^{\mathrm{e}}$ & $63.33^{\mathrm{de}}$ & $64.1 b^{\text {cde }}$ & $6.93^{\mathrm{a}}$ & $376.12^{\mathrm{a}}$ & $1.25^{\mathrm{a}}$ \\
\hline & 150 & $36.00^{\mathrm{d}}$ & $64.83^{\mathrm{e}}$ & $64.73^{b c}$ & $6.98^{\mathrm{a}}$ & $371.22^{\mathrm{a}}$ & $1.23^{\mathrm{a}}$ \\
\hline \multirow{4}{*}{ Shewa Robit } & 0 & $36.16^{\mathrm{f}}$ & $66.06^{\mathrm{d}}$ & $59.00^{\mathrm{e}}$ & $6.1^{c}$ & $220.26^{\mathrm{f}}$ & $0.73^{\mathrm{f}}$ \\
\hline & 50 & $38.00^{\mathrm{c}}$ & $66.50^{\mathrm{c}}$ & $65.73^{\mathrm{ab}}$ & $6.6^{\mathrm{b}}$ & $293.72^{\mathrm{d}}$ & $0.97^{\mathrm{d}}$ \\
\hline & 100 & $39.00^{\mathrm{b}}$ & $68.33^{\mathrm{b}}$ & $66.51^{\mathrm{ab}}$ & $6.3^{b c}$ & $317.22^{\mathrm{bc}}$ & $1.05^{\mathrm{bc}}$ \\
\hline & 150 & $40.00^{\mathrm{a}}$ & $71.66^{\mathrm{a}}$ & $67.75^{\mathrm{a}}$ & $6.5^{\mathrm{b}}$ & $325.00^{\mathrm{b}}$ & $1.08^{\mathrm{b}}$ \\
\hline LSD $(0.05)$ & & 0.33 & 1.53 & 2.57 & 0.4 & 18.72 & 0.06 \\
\hline CV (\%) & & 3.75 & 2.03 & 3.41 & 4.46 & 5.17 & 5.17 \\
\hline
\end{tabular}

Means with the same letter(s) in a column are nonsignificant at $(P \leq 0.05)$; $C V=$ coefficient of variance, LSD $=$ least significant difference, and NS = nonsignificant.

maturity especially timely rainfall throughout growing season. In addition, the $\mathrm{P}$ supplied from NPS fertilizer might have contributed for root proliferation contributing for improved nutrient uptake, thereby improving the increase in size and development of the plants. Consistent with this suggestion, the study in [37] indicated maximum (74.79) height of the plant of mung bean with application of $50-70 \mathrm{~kg} \mathrm{NP} \mathrm{ha}^{-1}$. The application of $\mathrm{S}$ enhances crop growth and increases nutrient uptake by the crop [38]. This study also corroborates the results of [39], who reported maximum plant height $(99.72 \mathrm{~cm})$ with maximum rate of NPS application $(150 \mathrm{~kg}$ NPS $\mathrm{ha}^{-1}$ ) for common bean variety Nasir.

3.3.2. Number of Primary Branches. Results indicated that branch number was notably affected by the two-way interaction of NPS rates and varieties. Significantly, the highest (6.98) branch number was recorded from interaction fertilizer composed of NPS at rate of $150 \mathrm{~kg} \mathrm{ha}^{-1}$ with variety N-26, whereas the lowest branch number primary (6.1) was obtained from Shewa Robit with no fertilizer applied (Table 2). Thus, the highest mean was observed due to genetically different characteristics of varieties, and increased NPS fertilizer rate can enhance crop growth. The amounts of primary branches per plant were increased due to increased application of blended NPS fertilizer. This implies that higher vegetative growth was formed when there is higher availability of nutrients supplied from blended NPS fertilizer. Increased number of branch plant ${ }^{-1}$ was formed for the fact that vigorous growth by the plants is a result of better photosynthetic activities with adequate availability of nutrients at vegetative growth stages [33]. The study in [33] reported significantly higher (5.34) amount of branches plant $^{-1}$ at maximum application of fertilizer $(150 \mathrm{Kg}$ NPS $\left.\mathrm{ha}^{-1}\right)$. Furthermore, Jawahar et al. observed significantly higher (5.91) number of branches plant ${ }^{-1}$ with the addition of $40 \mathrm{~kg} \mathrm{P}_{2} \mathrm{O}_{5} \mathrm{ha}^{-1}$ on mung bean production. The result was also consistent with the research finding of [40].

3.3.3. Leaf Area. Leaf area was significantly affected by the two-way interaction between NPS rates and varieties. Accordingly, the maximum $\left(376.12 \mathrm{~cm}^{2}\right)$ leaf area was recorded from interaction of fertilizer composed of NPS at rate $(100 \mathrm{~kg}$ $\mathrm{ha}^{-1}$ ) and variety $\mathrm{N}-26$, whereas minimum leaf area $\left(220.26 \mathrm{~cm}^{2}\right)$ was obtained from variety Shewa Robit with no fertilizer applied (Table 2). Thus, the maximum mean leaf area was observed due to genetically different characteristics of varieties and increased NPS fertilizer rate, which can enhance leaf area. The highest leaf area plant ${ }^{-1}$ might also be attributed to the improved photosynthesis process following better supply of nutrients in balanced quantity to the plants at growing stages. This result is consistent with the findings of [41]. In contrast, the low leaf area was found from the treatment with application of $57 \mathrm{~kg} \mathrm{P} \mathrm{ha}^{-1}$ rather than that recorded at rate application of $\mathrm{P} 38 \mathrm{~kg} \mathrm{ha}^{-1}$. In this result, also low leaf area was recorded from the treatment with addition of $150 \mathrm{~kg} \mathrm{ha}^{-1}$ NPS rather than that recorded at rate application of blended $100 \mathrm{~kg} \mathrm{ha}^{-1}$ NPS.

3.3.4. Leaf Area Index. The two-way interaction between NPS rates and varieties was found to be significant $(P \leq 0.05)$ on leaf area index. Significantly, the highest leaf area index (1.25) was recorded from interaction of fertilizer composed of NPS at rate $\left(100 \mathrm{~kg} \mathrm{ha}^{-1}\right)$ with variety $\mathrm{N}-26$, whereas the lowest leaf area index (0.73) was obtained from Shewa Robit with no fertilizer applied (Table 2). The greater in leaf area index resulted from improved availability of essential nutrients such as $\mathrm{N}, \mathrm{P}$, and $\mathrm{S}$, which can boost physiological process, which in turn improves growth of leaf area [42]. Supporting this finding, the study in [43] recorded a significant increase in leaf area index of soybean following $\mathrm{P}$ application.

\subsection{Yield and Yield Components}

3.4.1. Number of Pods per Plant. The number of pods per plant was highly influenced by the two-way interaction effect between NPS rates and varieties. The maximum (53.26) pods number was recorded for Shewa Robit at rate of $150 \mathrm{~kg} \mathrm{ha}^{-1}$, whereas the lowest pod number (30.40) was also obtained from Shewa Robit when no fertilizer was applied (Table 3). Thus, the greater number of pods per plant with the addition of NPS fertilizer was due to immediate supply of fertilizer 
TABLE 3: Interaction effects of varieties and blended NPS fertilizer rates on number of pods (PN) per plant, and number of seeds (SN) per pod, 1000-seed weight (g), and harvest index (\%).

\begin{tabular}{|c|c|c|c|c|c|}
\hline Varieties & NPS rate $\left(\mathrm{kg} \mathrm{ha}^{-1}\right)$ & No. of pods per plant ${ }^{-1}$ & No. of seeds per pod ${ }^{-1}$ & 1000 -seed weight $(\mathrm{g})$ & HI (\%) \\
\hline \multirow{4}{*}{$\mathrm{N}-26$} & 0 & $30.83^{\mathrm{d}}$ & $8.11^{\mathrm{c}}$ & $50.367^{\mathrm{c}}$ & $0.31^{\mathrm{cd}}$ \\
\hline & 50 & $42.66^{\mathrm{c}}$ & $9.56^{\mathrm{b}}$ & $53.700^{\mathrm{b}}$ & $0.32^{\mathrm{b}}$ \\
\hline & 100 & $49.53^{\mathrm{b}}$ & $11.86^{\mathrm{ab}}$ & $55.683^{\mathrm{a}}$ & $0.34^{\mathrm{a}}$ \\
\hline & 150 & $50.96^{\mathrm{b}}$ & $11.96^{\mathrm{a}}$ & $55.800^{\mathrm{a}}$ & $0.34^{\mathrm{a}}$ \\
\hline \multirow{4}{*}{ Shewa Robit } & 0 & $30.40^{\mathrm{d}}$ & $6.53^{f}$ & $41.283^{\mathrm{f}}$ & $0.30^{\mathrm{de}}$ \\
\hline & 50 & $47.60^{\mathrm{c}}$ & $7.05^{\mathrm{e}}$ & $43.755^{\mathrm{e}}$ & $0.30^{\mathrm{e}}$ \\
\hline & 100 & $52.78^{\mathrm{a}}$ & $7.6^{\mathrm{d}}$ & $46.948^{\mathrm{d}}$ & $0.31^{\mathrm{c}}$ \\
\hline & 150 & $53.26^{\mathrm{a}}$ & $7.9^{\mathrm{cd}}$ & $46.938^{\mathrm{d}}$ & $0.32^{\mathrm{b}}$ \\
\hline LSD $(0.05)$ & & 3.91 & 0.49 & 0.66 & 8.13 \\
\hline CV (\%) & & 7.26 & 4.36 & 1.15 & 2.14 \\
\hline
\end{tabular}

Numbers with the same letter(s) within a column are nonsignificant at $P \leq 0.05$; CV $=$ coefficient of variance and LSD $=$ least significant difference.

composed of NPS to the plants from inorganic fertilizer enhancing photosynthetic activities, thereby improving vegetative growth and development, which increased the production of pods upon translocation. This study is consistent with research findings of [33]. The study in [44] reported significant effect of NP fertilizers on pod production per plant of mung bean with the maximum number of pods in each plant (30.45) obtained at $52.5 \mathrm{~kg} \mathrm{~N} \mathrm{ha}^{-1}$ and $26 \mathrm{~kg} \mathrm{P}_{2} \mathrm{O}_{5} \mathrm{ha}^{-1}$. This finding is consistent with the result of [45]. Similarly, the study in [35] reported a corresponding increase in pods number (2.31 to 10.62) when $\mathrm{P}$ rate increased from nil to $39.6 \mathrm{~kg} \mathrm{ha}^{-1}$, which implies that the addition of $\mathrm{P}$ fertilizer could contribute to promoting the formation of nodes and pods in legumes. Further, research conducted by [46] indicated that pods number of common bean significantly increased with increased rate of $\mathrm{P}$ up to the highest rate of $92 \mathrm{~kg} \mathrm{P}_{2} \mathrm{O}_{5} \mathrm{ha}^{-1}$.

3.4.2. Number of Seeds per Pod. The result revealed that seeds number per pod was also strongly influenced by the two-way interaction between NPS rates and varieties. There were significant increases in the number of seeds per pod with increase in blended NPS rate over control. Significantly, variety N-26 had higher pods number with increased NPS rate than variety Shewa Robit (Table 3). Variety N-26 produced the highest (11.96) seeds number pod $^{-1}$ at $150 \mathrm{~kg}$ $\mathrm{ha}^{-1}$, whereas the lowest (6.53) seeds number pod ${ }^{-1}$ was found for Shewa Robit at nil rate fertilizer (Table 3). The increase in the amount of seeds per pot with increased NPS rates is probably due to the higher vegetative growth and improved branching with increasing production of pod. The result was consistent with the research findings of [47] who reported significant interaction effect of NPS fertilizers rates and mung bean varieties on seed $\operatorname{pod}^{-1}$ of mung bean with the maximum amount of seeds pod ${ }^{-1}$ (8.84) obtained at $150 \mathrm{~kg}$ NPS ha ${ }^{-1}$ for variety N-26. In this study, the highest seeds number per pod $^{-1}$ could probably be due to the combination of photosynthesis function of $\mathrm{N}$, seed formation ability of $\mathrm{P}$, and metabolic energy ability of S $[48,49]$. This finding is also in line with the result of [50]. The finding of this result is also supported by [40]. However, the current study is not consistent with the result of [51], who reported nonsignificant effect of main effects of $\mathrm{N}$ and $\mathrm{P}$ as well as their interactions on the amount of seeds pod $^{-1}$ of common bean.

3.4.3. 1000-Seed Weight. 1000-seed weight was significantly $(P \leq 0.05)$ influenced by the two-way interaction between NPS rates. The maximum 1000 -seed weight $(55.8 \mathrm{~g})$ was recorded from interaction of $150 \mathrm{~kg}$ NPS ha ${ }^{-1}$ application with variety $\mathrm{N}-26$, followed by the maximum (55.68 g) obtained from interaction $100 \mathrm{~kg}$ NPS ha ${ }^{-1}$ with variety $\mathrm{N}-26$, whereas the minimum 1000 -seed weight $(41.28 \mathrm{~g})$ was found from Shewa Robit variety with no fertilizer applied (Table 3 ). Variety $\mathrm{N}-26$ produced significantly maximum thousand-seed weight with increased NPS fertilizer rate than variety Shewa Robit. Such disparity in thousand-seed weight among the varieties may be attributed to genetically different characteristics of varieties and increase in NPS fertilizer rate over the control. This result is confirmed by the finding of [52], who determined that 1000-seed weight increased with $\mathrm{P}$ levels. This study is also in line with [53], who reported that the maximum $(51.6 \mathrm{~g})$ of mung bean was recorded at rate of $60 \mathrm{~kg} \mathrm{P} \mathrm{ha}{ }^{-1}$ for 1000 -seed weight, while lowest 1000 -seed weight $(46.96 \mathrm{gm})$ was found for control treatment.

This is the fact that assimilated photosynthesis can be translocated from vegetative plant parts to the seed, thus considerably enhancing seed weight. The increase in 1000grain weight showed that macronutrients along with micronutrients (i.e., S) are necessary for healthier and robust seeds in common bean [54]. Thus, the result is consistent with findings of [55]. The result is also supported by the findings of [44].

3.4.4. Aboveground Dry Biomass. For the studied mung bean plant, aboveground dry biomass was also significantly $(P \leq 0.05)$ influenced by the three-way interaction of NPS rates, varieties, and methods of application. For all varieties, aboveground dry biomass significantly increased with increase in blended NPS rate with drilling method of fertilizer application (Table 4). The maximum dry biomass $(4273.7 \mathrm{~kg}$ $\mathrm{ha}^{-1}$ ) was obtained from interaction of $150 \mathrm{~kg} \mathrm{ha}^{-1}$ blended NPS fertilizer with variety $\mathrm{N}-26$ from the combination of drilled application followed by the same variety $(4267.7 \mathrm{~kg}$ 
TABLE 4: Interaction effects of varieties, blended NPS fertilizer rates, and application methods on aboveground dry biomass (kg) and grain yield (g).

\begin{tabular}{|c|c|c|c|c|c|}
\hline \multirow{3}{*}{ Varieties } & \multirow{3}{*}{ NPS rates $\left(\mathrm{kg} \mathrm{ha}^{-1}\right)$} & \multirow{2}{*}{\multicolumn{2}{|c|}{ AGDM $\left(\mathrm{kg} \mathrm{ha}^{-1}\right)$}} & \multicolumn{2}{|c|}{ GY $\left(\mathrm{kg} \mathrm{ha}^{-1}\right)$} \\
\hline & & & & \multicolumn{2}{|c|}{ Appl. methods } \\
\hline & & Drilling & Broadcasting & Drilling & Broadcasting \\
\hline \multirow{4}{*}{$\mathrm{N}-26$} & 0 & $3211.1^{\mathrm{g}}$ & $3185.3^{\mathrm{g}}$ & $1011.0^{\mathrm{h}}$ & $1000.1^{\mathrm{h}}$ \\
\hline & 50 & $3872.4^{\mathrm{e}}$ & $3871.0^{\mathrm{e}}$ & $1274.2^{\mathrm{e}}$ & $1244.2^{\mathrm{f}}$ \\
\hline & 100 & $4267.7^{\mathrm{a}}$ & $4209.1^{\mathrm{abc}}$ & $1537.6^{\mathrm{a}}$ & $1459.9^{\mathrm{b}}$ \\
\hline & 150 & $4273.7^{\mathrm{a}}$ & $4226.3^{\mathrm{ab}}$ & $1539.2^{\mathrm{a}}$ & $1468.4^{\mathrm{b}}$ \\
\hline \multirow{4}{*}{ Shewa Robit } & 0 & $3104.7^{\text {gh }}$ & $3038.1^{\mathrm{h}}$ & $953.7^{\mathrm{i}}$ & $943.4^{\mathrm{i}}$ \\
\hline & 50 & $3463.3^{\mathrm{f}}$ & $3469.9^{\mathrm{f}}$ & $1066.8^{\mathrm{g}}$ & $1040.4^{\mathrm{g}}$ \\
\hline & 100 & $4097.9^{\mathrm{cd}}$ & $4045.6^{\mathrm{d}}$ & $1315.4^{\mathrm{d}}$ & $1261.7^{\mathrm{ef}}$ \\
\hline & 150 & $4155.1 b^{c d}$ & $4127.9^{\mathrm{bcd}}$ & $1367.6^{c}$ & $1347.3^{\mathrm{c}}$ \\
\hline 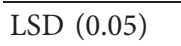 & & \multicolumn{2}{|c|}{112.09} & \multicolumn{2}{|c|}{27.71} \\
\hline CV (\%) & & \multicolumn{2}{|c|}{1.77} & \multicolumn{2}{|c|}{1.36} \\
\hline
\end{tabular}

Numbers with the same letter in column are nonsignificant at 5\% level of significance; LSD (0.05): least significant difference at 5\% level; CV: coefficient of variation; AGDB: aboveground dry biomass, and GY: grain yield.

$\mathrm{ha}^{-1}$ ) at rate of $100 \mathrm{~kg} \mathrm{ha}^{-1}$ blended NPS using drilling application method, while the minimum aboveground dry biomass $\left(3038.1 \mathrm{~kg} \mathrm{ha}^{-1}\right.$ ) was obtained from Shewa Robit with no fertilizer application (Table 4).

The study in [33] reported the significantly highest aboveground biomass for mung bean variety N-26 at application of $100 \mathrm{~kg} \mathrm{ha}^{-1}$ with $20 \mathrm{~cm}$. The authors of $[41,56]$ also reported an increase in total dry matter per plant with $\mathrm{N}$ application for French bean and common bean, respectively. This result is consistent with the findings of [39], who reported a significant linear response of aboveground dry biomass to application of different levels of NPS in common bean. According to [57], there is the addition of $\mathrm{P}$ fertilizer with soil low in available $P$ of acidic Nitisols, and an increase in the aboveground biomass of faba bean was found. The study in [35] also reported that P fertilization on soya bean did not significantly affect the aboveground dry biomass.

3.4.5. Grain Yield. The analysis of variance revealed that grain yield was significantly $(P \leq 0.05)$ influenced by the three-way interaction of NPS rates, varieties, and application method. The maximum grain yield $\left(1539.2 \mathrm{~kg} \mathrm{ha}^{-1}\right)$ was found from interaction of $150 \mathrm{~kg} \mathrm{ha}^{-1}$ blended NPS fertilizer rate with variety $\mathrm{N}-26$ using drilled application method followed by maximum $\left(1537.6 \mathrm{~kg} \mathrm{ha}^{-1}\right)$ grain yield recorded from the interaction of $100 \mathrm{~kg} \mathrm{ha}^{-1}$ blended NPS fertilizer rate with the same variety and application method, but no statistical difference between them (Table 4), while, significantly, the lowest yield $\left(943.4 \mathrm{~kg} \mathrm{ha}^{-1}\right)$ was observed from interaction of variety Shewa Robit with nil fertilizer applied (Table 5). This highest value was formed due to significant application of fertilizer composed of NPS. N at early growth stages promoted vegetative growth and created conditions conducive to high yield and played a critical role for chlorophyll formation and protein, directly increasing the plant protein content, thereby boosting yield [48]. In accord with the present finding, the authors of $[33,47]$ reported that grain yield of mung bean is significantly affected by two-way interaction effects of mung bean varieties and blended NPS rate.
Phosphorus enhanced cellular respiration in the production of the starch, protein, and fats plays a fundamental role in metabolism and energy producing reaction, building phospholipids, and nucleic acid and stimulates blooming and seed formation, which could increase yield [58].

This result is consistent with that of [48], who described that the interaction effects of $\mathrm{N}$ and $\mathrm{P}$ levels on seed yield of mung bean were highly significant. The study in [59] who reported the application of $\mathrm{P}$ and $\mathrm{S}$ could maximize mung bean production. The study in [60] also reported highly significant effect of $\mathrm{P}$ fertilizer application rate on seed yield of mung bean and common bean. The study in [46] also reported that the application of $\mathrm{P}$ could maximize the yield of haricot bean. According to [13], $\mathrm{P}$ is considered to be important for stimulated root development and seed formation. Application method significantly influenced grain yield with increase in NPS rate (Table 4).

Application method of drilling is suitable method than broadcasting. This could be due to avoiding easy evaporation of mobile nutrients such as N, S and can keep P fertilizer within the soil system for the adequate supply to crops. Disparity of broadcast results in nonuniform growth, wasting of fertilizer, and decreasing the usage coefficient of plant [61]. Drilling method for $\mathrm{N}$-fertilizers in nutrient deficient soils may offer increased fertilizer absorption by the plant [62].

3.4.6. Harvest Index. Harvest index was influenced significantly $(P \leq 0.05)$ due to the two-way interaction of fertilizer rates composed of NPS and varieties. The maximum harvest index (0.34) was recorded from interaction effect of $150 \mathrm{~kg}$ $\mathrm{ha}^{-1}$ blended NPS fertilizer with variety N-26 followed by $100 \mathrm{~kg} \mathrm{NPS} \mathrm{ha}{ }^{-1}$ with the same variety, but no statistical difference (Table 3 ). The minimum harvest index (0.30) was obtained from Shewa Robit with no fertilizer applied (Table 3). This study is consistent with the finding of $[39,47]$. The study in [47] also reported that the maximum harvest index was obtained from N-26 variety at NPS rate of $150 \mathrm{~kg}$ $\mathrm{ha}^{-1}$, which was followed by the same variety N-26 (39.05\%) 
TABLE 5: Partial budget analysis of interaction effect of varieties and blended NPS rates with the application method on yield of mung bean during 2019 cropping season at Humbo.

\begin{tabular}{|c|c|c|c|c|c|c|c|c|}
\hline Method & $\begin{array}{l}\text { Treatn } \\
\text { Rates }\end{array}$ & Varieties & GAY & AJAY & GFP & TVC & NB & MRR (\%) \\
\hline \multirow{4}{*}{ Dr } & 0 & Shewa Robit & 953.7 & 858.33 & 30041.55 & 0 & 30041.55 & - \\
\hline & 50 & Shewa Robit & 1066.8 & 960.12 & 33604.2 & 800 & 32804.2 & 345 \\
\hline & 100 & Shewa Robit & 1315.4 & 1183.86 & 41435.1 & 1500 & 39935.1 & 1019 \\
\hline & 150 & Shewa Robit & 1367.6 & 1230.84 & 43079.4 & 2200 & 40879.4 & 135 \\
\hline \multirow{4}{*}{$\mathrm{Br}$} & 0 & Shewa Robit & 943.4 & 849.06 & 29717.1 & 0 & 29717.1 & - \\
\hline & 50 & Shewa Robit & 1040.4 & 936.36 & 32772.6 & 800 & 31972.6 & 282 \\
\hline & 100 & Shewa Robit & 1261.7 & 1135.53 & 39743.55 & 1500 & 38243.55 & 896 \\
\hline & 150 & Shewa Robit & 1347.3 & 1212.57 & 42439.95 & 2200 & 40239.95 & 285 \\
\hline \multirow{4}{*}{ Dr } & 0 & $\mathrm{~N}-26$ & 1011 & 909.9 & 31846.5 & 0 & 31846.5 & - \\
\hline & 50 & $\mathrm{~N}-26$ & 1274.2 & 1146.78 & 40137.3 & 800 & 39337.3 & 936 \\
\hline & 100 & $\mathrm{~N}-26$ & 1537.6 & 1383.84 & 48434.4 & 1500 & 46934.4 & 1085 \\
\hline & 150 & $\mathrm{~N}-26$ & 1539.2 & 1385.28 & 48484.8 & 2200 & 46284.8 & $\mathrm{D}$ \\
\hline \multirow{4}{*}{$\mathrm{Br}$} & 0 & $\mathrm{~N}-26$ & 1000.1 & 900.09 & 31503.15 & 0 & 31503.15 & 0 \\
\hline & 50 & $\mathrm{~N}-26$ & 1244.2 & 1119.78 & 39192.3 & 800 & 38392.3 & 861 \\
\hline & 100 & $\mathrm{~N}-26$ & 1459.9 & 1313.91 & 45986.85 & 1500 & 44486.85 & 871 \\
\hline & 150 & $\mathrm{~N}-26$ & 1468.4 & 1321.56 & 46254.6 & 2200 & 44054.6 & $\mathrm{D}$ \\
\hline
\end{tabular}

$\mathrm{Dr}=$ drilled application method, $\mathrm{Br}=$ broadcasting, GAY = gross average yield, AJAY = adjusted average yield $(-10 \%)$, GFP = gross field price $($ mung bean price $=35 \mathrm{ETB} \mathrm{kg}^{-1}, \mathrm{TVC}=$ total variable cost, and $\mathrm{NB}=$ net benefit $\left(\mathrm{ETB} \mathrm{ha}^{-1}\right)$.

at rate of $100 \mathrm{~kg} \mathrm{NPS} \mathrm{ha}^{-1}$. The study in [37] also reported an increase in harvest index of mung bean in response to addition of $\mathrm{N}$ and $\mathrm{P}$.

3.5. Partial Budget Analysis. It is used to understand efficiency and economics of inputs and outputs of crop production. From this study, the mean yields of mung bean were estimated. The mean yields of mung bean were adjusted downward by $10 \%$ to reflect the difference between the experimental and farmers' field yields [24].

From the use of various interactions of fertilizers composed of NPS with varieties and with application methods, the total variable cost and net benefits were estimated. The total variable cost (TVC) was estimated during field experimental period that included the cost of fertilizers and cost of labor for fertilizers applications (Table 5). Daily labor cost during experimental period was 100 ETB per person per day, and the field price of mung bean yield during harvesting period was $35 \mathrm{ETB} \mathrm{kg}^{-1}$. The total variable cost (TVC) was subtracted from gross field prices (GFP) to obtain net benefits (NB). After estimating net benefits, the treatments were arranged in increasing order of total variable costs to identify dominated and nondominated treatments. In this study, from sixteen treatments, three were dominated, and thirteen were nondominated (Table 5).

Dominated treatments were absent from subsequent steps in the marginal analysis, whereas, for nondominated treatments, insignificant rate of returns was calculated. According to [24], the thirteen nondominated treatments gave more than $100 \%$ marginal rate of return (Table 5). Marginal rate of return (MRR) is a characteristic of the change from one treatment to another and since dominated treatments are not included, it will always be positive. So below $100 \%$ and/or negative MRR was considered as low and unacceptable to farmers, because such returns would not return capital and other related costs, and something would not be added to the cost of capital to repay the producers for the time and effort spent.

The recommendation is not necessarily the treatment with the highest marginal rate of return compared to neither that of next lowest cost, or the treatment with the highest net benefit, nor the treatment with the highest yield. The identification of a recommendation requires a careful marginal analysis using an appropriate minimum rate of return [24]. In this study, the partial budget analysis indicated that the highest net benefit was obtained from variety $\mathrm{N}-26$ supplied with fertilizer composed of NPS at rate of $100 \mathrm{~kg} \mathrm{ha}^{-1}$ using drilling application $5 \mathrm{~cm}$ below seed, which gave highest net benefits of 46,934.4 $\mathrm{ETB} \mathrm{ha}^{-1}$ (Table 5).

\section{Conclusion}

The results of this study revealed that mung bean varieties responded differently to different rates of NPS fertilizer. Further, the economic return obtained from different varieties of mung bean at different rates of NPS varied. This suggests that we need to apply agronomic and economic optimum rates of NPS fertilizer for mung bean varieties differently in order to obtain the maximum grain yield and economic return. Thus, though it is for one year as far as there is enough rainfall particularly during planting and even if it is intermittent until grain filling, it can be recommended that, for better production of mung bean in Humbo districts of Wolaita Zone and in areas similar to the study area, producers shall better use variety N-26 supplied with blended NPS fertilizer at rate $100 \mathrm{~kg} \mathrm{ha}^{-1}$ using drilling application $5 \mathrm{~cm}$ below the seed.

\section{Data Availability}

The data used to support the findings of this study are available from the corresponding author upon request. 


\section{Conflicts of Interest}

The authors declare no conflicts of interest.

\section{Authors' Contributions}

FM carried out the experiment. DS initiated and suggested the experiment and carried out statistical analysis. MB performed laboratory measurements and reviewed, finalized the study, and wrote the manuscript.

\section{Acknowledgments}

The authors would like to acknowledge Wolaita Sodo University for financial support.

\section{References}

[1] M. A. Khan, K. Naveed, K. Ali, B. Ahmad, and S. Jan, "Impact of mungbean-maize intercropping on growth and yield of mungbean. weed science society of Pakistan department of weed science," Pakistan Journal of Weed Science Research, vol. 18, no. 2, pp. 191-200, 2012.

[2] M. Rahman, M. Bhuiyan, G. Sutradhar, M. Rahman, and A. Paul, "Effect of phosphorus, molybdenum and rhizobium inoculation on yield and yield attributes of mungbean," International Journal of Sustainable Crop Production, vol. 3, no. 6, pp. 26-33, 2008.

[3] M. S. Anjum, Z. I. Ahmed, and C. A. Rauf, "Effect of rhizobium inoculation and nitrogen fertilizer on yield and yield components of mungbean," International Journal of Agriculture and Biology, vol. 8, no. 2, pp. 238-240, 2006.

[4] G. Kidane, Agricultural Based Livelihood Systems in DryLands in the Context of Climate Change, Inventory of Adaptation Practices and Technologies of Ethiopia, Rome, Italy, 2010.

[5] EEPA (Ethiopian Export Promotion Agency), Ethiopian Pulses Profile. Ethiopian Export Promotion Agency, Product Development \& Market Research Directorate, Addis Ababa, Ethiopia, 2004.

[6] ECX (Ethiopian Commodity Exchange), ECX Rings Bell for Mung Bean, ECX, Addis Ababa, Ethiopia, 2014.

[7] CSA (Central Statistical Authority), Report on the Preliminary Results of Area, Production and Yield of Temporary Crops in Ethiopia, CSA, Addis Ababa, Ethiopia, 2018.

[8] MOA (Ministry of Agriculture), Agro-Ecological Zones of Ethiopia. Natural Resources Management and Regulatory Department, Ministry of Agriculture, Addis Ababa, Ethiopia, 2011.

[9] A. Asrat, G. Fekadu, A. Fetsum, and R. Yayis, "Analysis of multi-environment grain yield trials in mungbean (Vigna radiate (L.) Wilczek based on GGE bipot in Southern Ethiopia," Journal of Agriculture, Science and Technology, vol. 14, pp. 389-398, 2012.

[10] G. N. Arain, Crop Manager Agronomy Center Pivot Irrigation System Valley Irrigation in Pakistan Private Limited, Pakistan Private Limited, Karachi, Pakistan, 2012.

[11] J. G. Davis and M. A. Brick, Fertilizing Dry Beans, Colorado State University, Fort Collins, CO, USA, 2009.

[12] R. Kumar, Y. V. Singh, S. Singh, A. M. Latare, and P. K. Mishra, "Effect of phosphorus and sulphur nutrition on yield attributes yield of mungbean (Vigna radiate
L. Wilczek)," Journal of Chemical and Pharmaceutical Research, vol. 4, no. 5, pp. 2571-2573, 2012.

[13] L. J. Havlin, J. D. Beaton, S. L. Tisdale, and W. L. Nelson, Soil Fertility and Fertilizers: An Introduction to Nutrient Management, Pearson, London, UK, 6th edition, 2004.

[14] ATA (Agricultural Transformation Agency), Soil Fertility Mapping and Fertilizer Recommendation in Ethiopia: Update of EthioSIS Project and Status of Fertilizer Blending Plants, ATA (Agricultural Transformation Agency), Addis Ababa, Ethiopia, 2015.

[15] K. C. Suda and R. C. Sharma, "Sulphur needs of potato under rainfed conditions in Shimla hills," in Potato Global Research and Development, S. M. Paul, G. Khurana, S. Shekhawat, S. K. Pandey, and B. S. Singh, Eds., pp. 889-899, Indian Potato Association, Shimla, India, 2002.

[16] A. Muhammad, A. Amjed, I. Muhammad, W. Syed, R. Shahid, and A. Amana, "P effects on growth and yield parameters of mungbean," Science International, vol. 26, no. 4, pp. 18211824, 2014.

[17] L. Fanuel and W. Walelign, "Growth, light interception, radiation use efficiency and productivity of mungbean vigna radiata Wilczek (fabaceae) cultivars as influenced by sowing date," Ethiopian Journal of Biological Sciences, vol. 12, no. 2, pp. 117-133, 2013.

[18] T. Endrias and G. Yohanis, Geographic Information System and Remote Sensing Mapping Using Environmental Factors: A Case of Humbo Woreda, Adis Abeba University, Addis Ababa, Ethiopia, 2015.

[19] G. Gee and J. Bauder, "Particle size analysis in methods of soil analysis," Chemical and Microbiological Propertiespp. 383-411, Soil Science Society of America, Madison. WI, USA, 2nd edition, 1986.

[20] M. Jackson, Soil Chemical Analysis, Prentice Hall, Hoboken, N.J, USA, 1958.

[21] A. Mehlich, "Mehlich 3 soil test extractant: a modification of mehlich 2 extractant," Communications in Soil Science and Plant Analysis, vol. 15, no. 12, pp. 1409-1416, 1984.

[22] A. Walkley and I. A. Black, "An examination of the degtjareff method for determining soil organic matter, and a proposed modification of the chromic acid titration method," Soil Science, vol. 37, no. 1, pp. 29-38, 1934.

[23] V. Reeuwijk, Procedures for Soil Analysis, International Soil Reference and Information Center, Wageningen, Netherlands, 4th edition, 1993.

[24] CIMMYT, From Agronomic Data to Farmer Recommendations: An Economics Work Book, The International Maize and Wheat Improvement Center, Mexico, 1988.

[25] SAS (Statistical Analysis System Institute), SAS Statistical Guide for Personal Computers, SAS Institute, Cary, NC, USA, 2008.

[26] K. A. Gomez and A. A. Gomez, Statistical Procedures for Agricultural Research, John Willey and Sons, Hoboken, NJ, USA, 2nd edition, 1984.

[27] SADAFF (South African Department of Agriculture, Forestry and Fisheries), Mungbean Production Guideline, SADAFF, Los Angeles, CA. USA, 2010.

[28] Ethio-SIS (Ethiopia Soil Fertility Status), Fertilizer Recommendation Atlas of the Southern Nations, Nationalities and Peoples' Regional State, Ethio-SIS (Ethiopia Soil Fertility Status), Addis Ababa, Ethiopia, 2016.

[29] R. Bruce and G. Rayment, Analytical Methods and Interpretations Used by the Agricultural Chemistry Branch for Soil and Land Use Surveys, Queensland Department of Primary Industries, Brisbane, Australia, 1982. 
[30] P. Charman and M. Roper, "Soil organic matter," in SoilsTheir Properties and Management, P. E. V. Charman and B. W. Murphy, Eds., pp. 276-285, Oxford University Press, Oxford, UK, 3rd edn. edition, 2007.

[31] R. H. Joseph, Soil Fertility Test Interpretation Phosphorus, Potassium, Magnesium, and Calcium, New Jersey Agricultural Experiment Station, New Brunswick, NJ, USA, 2000.

[32] A. Kelling, G. Bundy, M. Combs, and B. Peters, Optimum Soil Test Levels for Wisconsin, University of Wisconsin, Madison, WI, USA, 1999.

[33] K. Kawte, S. Dereje, and B. Mesfin, "Performance of mungbean (Vigna radiata L.) varieties at different NPS rates and row spacing at Kindo Koysha district, Southern Ethiopia," Cogent Food \& Agriculture, vol. 6, pp. 1-12, 2020.

[34] A. N. Ganeshamurthy and K. Sammi Reddy, "Effect of integrated use of farmyard manure and sulphur in a soybean and wheat cropping system on nodulation, dry matter production and chlorophyll content of soybean on swell-shrink soils in Central India," Journal of Agronomy and Crop Science, vol. 185, no. 2, pp. 91-97, 2000.

[35] T. Tesfaye and A. Balcha, "Effect of phosphorus application and varieties on grain yield and yield components of common bean (Phaseolus vulgaris L.)," American Journal of Plant Nutrition and Fertilization Technology, vol. 5, no. 3, pp. 79-84, 2015.

[36] N. Tadesse and N. Dechassa, Effect of Nitrogen and Sulphur Application on Yield Components and Yield of Common Bean (Phaseolus vulgaris L.) in Eastern Ethiopia, Haramaya University of Agriculture, Dire Wara, Ethiopia, 2017.

[37] M. A. Malik, A. M. Asghar, F. Saleem, and L. Mahmood, "Effect of nitrogen and phosphorus application on growth yield and quality of mungbean (Vigna radiata L," Pakistan Journal of Agricultural Sciences, vol. 40, pp. 3-4, 2003.

[38] S. Beza, "Response of chickpea (Cicer Aritienum L.) to sulphur and zinc nutrients application and rhizobium inoculation in North Western Ethiopia," M.Sc. Thesis, Haramaya University, pp. 1-28, Dire Wara, Ethiopia, 2017.

[39] S. Deresa, A. Demissie, A. Tekalign, and D. Belachew, "Response of common bean (Phaseolus vulgaris L.) varieties to rates of blended NPS fertilizer in Adola district, Southern Ethiopia," Journal of Plant Biology \& Soil Health, vol. 5, pp. 1-5, 2018.

[40] S. Jawahar, V. Vaiyapuri, K. Suseendran, C. Kalaiyarasan, and M. V. Sriramach, "Effect of sources and levels of sulphur on growth and yield of rice fallow blackgram (Vigna mungo)," International Research Journal of Chemistry, vol. 3, pp. 1-7, 2013.

[41] N. K. Veeresh, "Response of French bean (Phaseolus vulgaris L.) to fertilizer levels in northern transitional zone of Karnataka," M.Sc. (Agriculture) Thesis, University Agricultural Science, pp. 37-79, Dharwad, India, 2003.

[42] W. F. Bennett, Nutrient Deficiencies and Toxicities in Crop Plants, The American Psychopathological Society, New York, NY, USA, 1993.

[43] E. V. Tairo and P. A. Ndakidemi, "Bradyrhizobium japonicum inoculation and phosphorus supplementation on growth and chlorophyll accumulation in soybean (Glycine max L.)," American Journal of Plant Sciences, vol. 4, no. 12, pp. 22812289, 2013.

[44] Z. Yin, W. Guo, H. Xiao, J. Liang, X. Hao, and N. Dong, "Nitrogen, phosphorus, and potassium fertilization to achieve expected yield and improve yield components of mungbean," PLoS One, vol. 13, no. 10, 2018.
[45] P. B. Deshbhratar, P. K. Singh, A. P. Jambhulkar, and D. S. Ramteke, "Effect of sulphur and phosphorus on yield, quality and nutrient status of pigeon pea (Cajanus cajan)," Journal of Environmental Biology, vol. 31, pp. 933-937, 2010.

[46] S. Dereje, D. Nigussie, and G. Setegn, "Response of common bean cultivars to phosphorus application in boloso sore and Sodo zuria districts, southern Ethiopia," East African Journal of Sciences, vol. 9, pp. 49-60, 2015.

[47] B. Mulu, "Response of mungbean (vigna radiata L.) varieties to rates of blended NPS fertilizer in Kindo Koysha district, Southern Ethiopia," Msc.Thesis, Wolaita Sodo University, Wolaita Sodo, Ethiopia, 2019.

[48] O. Sadeghipour, R. Monem, and A. Tajali, "Production of mungbean (Vigna radiata L.) as affected by nitrogen and phosphorus fertilizer application," Journal of Applied Sciences, vol. 10, no. 10, pp. 843-847, 2010.

[49] M. Islam, A. Sabagh, K. Hasan, M. Akhter, and C. Barutçular, "Growth and yieldresponse of mungbean (Vignaradiata L.) as influenced by sulphur and boron application," Scientific Journal of Crop Science, vol. 6, no. 1, pp. 153-160, 2017.

[50] K. S. Shubhashree, "Response of rajmash (Phaseolus vulgaris L.) to the levels of nitrogen, phosphorus and potassium during Rabi in the northern transition zone," M.Sc. Thesis, Dharwad University of Agricultural Science, Dharwad, India, 2007.

[51] F. Negash and Y. Rezene, "Nitrogen and phosphorus fertilizers rate as affecting common bean production at Areka, Ethiopia," Journal of Agriculture and Crops, vol. 1, pp. 33-37, 2015.

[52] S. M. Khan, V. P. Singh, and A. Kumar, "Studies on effect of phosphorous levels on growth and yield of kharif mungbean (Vigna radiata L. wilczek)," Journal of Pure \& Applied Biosciences, vol. 5, no. 4, pp. 800-808, 2017.

[53] A. A. Imran, I. Khan, F. Inam, and F. Ahmad, "Yield and yield attributes of mungbean (Vignaradiata L.) cultivars as affected by phosphorous levels under different tillage systems," Cogent Food \& Agriculture, vol. 2, 2016.

[54] M. Lake and S. Jemaludin, "The response of common bean (Phaseoluse Vulgaris L.) to various levels of blended fertilizer," International Journal of Research in Agriculture and Forestry, vol. 5, pp. 15-20, 2018.

[55] A. Arega and M. Zenebe, "Common bean (Phaseolus vulgaris L.) varieties response to rates of blended NPKSB fertilizer at Arba Minch, Southern Ethiopia," Advances in Crop Science and Technology, vol. 7, no. 3, pp. 429-435, 2019.

[56] R. Singh, Y. Singh, O. N. Singh, and S. N. Sharma, "Effect of nitrogen and micronutrients on growth, yield and nutrient uptake by French bean," Indian Journal of Pulses Research, vol. 19, pp. 67-69, 2006.

[57] G. Agengew and A. Tsige, "The role of phosphorus fertilization on growth and yield of faba bean on acidic nitosol of central highland of Ethiopia," Ethiopian Journal of Science, vol. 29, pp. 177-182, 2006.

[58] R. Iqbal and I. Chauhan, "Relationship between different growth and yield parameters in maize under varying levels of phosphorus," Journal of Biological Sciences, vol. 3, pp. 921925, 2003.

[59] P. Singh, K. K. Yadav, S. F. Meena, B. Singh, and R. Singh, Effect of Phosphorus and Sulphur on Yield Attributes Yield and Nutrient Uptake of Mungbean (Vigna radiata L.) in Central Plain Zone of Punjab, India, Mata Gujri College (An Autonomous College), Fatehgarh Sahib, India, 2017.

[60] A. Ali, G. Abbas, Q. Mohy-ud-Din, K. Ullah, G. Abbas, and M. Aslam, "Response of mungbean (Vigna Radiata) to 
phosphatic fertilizer under arid climate," The Journal of Animal \& Plant Sciences, vol. 20, no. 2, pp. 83-86, 2010.

[61] M. J. Malakoti, Sustainable Agriculture and Yield Increase through Optimization of Fertilizer Usage in Iran, Agricultural Education, Farsi, Iran, (In Farsi), 2nd edition, 1999.

[62] V. A. Bandel, F. R. Mulford, and H. J. Bauer, "Influence of fertilizer source and placement on no-tillage corn," Journal of Fertilizer Issues, vol. 1, pp. 38-43, 1984. 